\title{
Pengaruh Audit Kinerja dan Penyajian Laporan Keuangan Terhadap Akuntabilitas Publik (Studi Kasus pada Skpd Kota Semarang)
}

\author{
Putri Asih, Widaryanti, Panca.W
}

STIE Pelita Nusantara Semarang

Email Corresponding: putriasihh@ gmail.com

\begin{abstract}
Abstrak
Penelitian ini bertujuan untuk mengetahui apakah audit kinerja dan penyajian laporan keuangan berpengaruh terhadap akuntabilitas publik. Populasi dalam penelitian ini adalah seluruh badan maupun dinas dalam Satuan Kerja Perangkat Daerah di Kota Semarang. Pengambilan sampel dilakukan dengan menggunakan metode Sampel Sensus dan jumlah sampel sebanyak 42 responden. Jenis data yang digunakan adalah data primer. Penelitian ini menggunakan kuesioner dalam pengumpulan datanya. Teknik uji yang dipakai adalah uji validitas, uji reliabilitas, uji asumsi klasik meliputi uji normalitas, uji multikolinearitas, dan uji heteroskedastisitas. Uji hipotesis pada penelitian ini menggunakan analisis regresi linier berganda. Variabel audit kinerja tidak berpengaruh terhadap akuntabilitas public sedangkan penyajian laporan keuangan berpengaruh positif dan signifikan terhadap akuntabilitas publik.
\end{abstract}

Kata Kunci: Audit Kinerja, Penyajian Laporan Keuangan, dan Akuntabilitas Publik

\begin{abstract}
This study aims to determine whether performance audits and financial statement presentation have an effect on public accountability. The population in this study were all agencies and offices included in the Regional Work Units in Semarang City. Sampling was done using the Census Sample method and the number of samples was 42 respondents. The type of data used is primary data. This study uses a questionnaire in data collection. The test technique used is the validity test, reliability test, classic assumption test including normality test, multicollinearity test, and heteroscedasticity test. Hypothesis testing in this study uses multiple linear regression analysis. The performance audit has no effect on public accountability. The presentation of financial statements has a positive and significant effect on public accountability.
\end{abstract}

Keywords: Performance Audit, Financial Statement Presentation, and Public Accountability 


\section{Pendahuluan}

\section{Latar Belakang}

Era reformasi Indonesia saat ini, sebagian besar masyarakat menuntut agar pemerintahan mampu mengelola otonomi daerah dan sistem pengelolaan keuangan daerah agar lebih baik, sehingga pemerintah dituntut untuk menyediakan semua informasi keuangan yang relevan secara jujur dan terbuka kepada masyarakat. Besarnya tuntutan terhadap pelaksanaan akuntabilitas publik akan menimbulkan implikasi bagi sebagian besar manajemen sektor publik untuk memberikan informasi, salah satunya melalui laporan keuangan. Peggy (2013) menyatakan bahwa masyarakat berhak untuk menuntut pertanggungjawaban atas pengaplikasian serta pelaksanaan pengelolaan keuangan daerah tersebut, karena kegiatan pemerintah adalah dalam rangka melaksanakan amanat rakyat.

Besarnya tuntutan terhadap pelaksanaan akuntabilitas publik akan menimbulkan implikasi bagi sebagian besar manajemen sektor publik untuk memberikan informasi, salah satunya melalui laporan keuangan. Scott dalam Darmawan (2014) menyatakan bahwa keberlangsungan suatu organisasi dipengaruhi oleh kemampuannya dalam menciptakan informasi yang terbuka, dan merata bagi semua pihak yang berkepentingan.

Akuntabilitas publik merupakan pertanggung jawaban pemerintah kepada masyarakat terkait dengan kegiatan yang menjadi tanggungjawabanya melalui penyajian laporan keuangan (Deddy \& Sherly, 2010 dalam Rahayu, 2011). Akuntabilitas menggambarkan suatu keadaan atau kondisi yang dapat dipertanggungjawabkan dalam pemberian informasi dan pengungkapan atas aktivitas dan kinerja finansial kepada pihak-pihak yang berkepentingan.

Besarnya tuntutan terhadap pelaksanaan akuntabilitas publik akan menimbulkan implikasi bagi sebagian besar manajemen sektor publik untuk memberikan informasi, salah satunya melalui laporan keuangan. Scott dalam Darmawan (2014) menyatakan bahwa keberlangsungan suatu organisasi dipengaruhi oleh kemampuannya dalam menciptakan informasi yang terbuka, dan merata bagi semua pihak yang berkepentingan.

Dalam meningkatkan sistem akuntabilitas maka harus diketahui faktor apa saja yang dapat mempengaruhi akuntabilitas, faktor tersebut salah satunya adalah penyajian laporan keuangan. Mardiasmo (2004), menyatakan bahwa penyajian laporan keuangan oleh pemerintah daerah adalah untuk memberikan informasi yang digunakan dalam pembuatan keputusan ekonomi, sosial, dan politik, serta sebagai bukti pertanggungjawaban (accountability) dan pengelolaan (stewardship) serta dapat memberikan informasi yang digunakan untuk mengevaluasi kinerja manajerial dan organisasionalnya.

Oleh sebab itu, untuk mengatasi hal tersebut pihak pertanggungjawaban publik melakukan rekayasa atas tindakan-tindakan yang berhubungan dengan laporan 
keuangan agar pertanggungjawaban yang dihasilkan sesuai dengan ketentuan-ketentuan yang berlaku sehingga terhindar dari manipulasi data yang tidak dapat dihindarkan.

Adapun variabel penelitian yang digunakan yaitu Audit Kinerja dan Penyajian Laporan Keuangan (variabel independent), serta Akuntabilitas Publik (variabel dependen). Tujuan yang hendak dicapai dalam penelitian ini adalah untuk menganalisis pengaruh audit kinerja dan penyajian laporan keuangan secara parsial maupun simultan terhadap akuntabilitas publik.

\section{Landasan Teori}

\section{Akuntabilitas Publik}

Menurut Mardiasmo (2009) akuntabilitas publik adalah kewajiban pemegang amanah (agent) untuk memberikan pertanggungjawaban, menyajikan, melaporkan, dan mengungkapkan segala aktivitas dan kegiatan yang menjadi tanggungjawabnya kepada pemberi amanah (principal) yang memiliki hak dan kewenangan untuk meminta pertanggungjawaban tersebut.

Pemerintah pusat maupun pemerintah daerah harus dapat menjadi subjek atas pemberian informasi dalam rangka memenuhi hak-hak publik, yaitu hak untuk mengetahui, hak untuk diberi informasi, dan hak untuk didengar aspirasinya.

Secara umum akuntabilitas dipahami sebagai kewajiban seseorang/lembaga untuk memberikan laporan yang memuaskan atas tindakan sebagai wewenang yang dimiliki atau diterima (satisfactory report), dan kewajiban membuktikan kinerja yang baik sesuai dengan ketentuan yang berlaku.

Akuntabilitas publik dapat dibagi menjadi dua macam yaitu akuntabilitas vertikal dan akuntabilitas horisontal. Menurut Mardiasmo (2009) Akuntabilitas vertikal adalah pertanggungjawaban atas pengelolaan dana kepada otoritas yang lebih tinggi. Misalnya, dari dinas ke pemerintahan daerah (pemerintah pusat).

\section{Tingkatan Akuntabilitas Publik}

Akuntabilitas dapat dilihat sebagai suatu tingkatan dengan lima tahap yang lebih banyak membutuhkan ukuran obyektif ke ukuran subyektif (Sadijarto, 2000) antara lain:

a. Probity and legality accountability

Hal ini menyangkut pertanggungjawaban penggunaan dana sesuai dengan anggaran yang telah disetujui dan sesuai dengan peraturan perundang-undangan yang berlaku.

b. Process accountability

Dalam hal ini digunakan proses, prosedur atau ukuran-ukiuran dalam melaksanakan kegiatan yang ditentukan.

c. Performance accountability

Pada level ini dilihat apakah kegiatan sudah efisien.

d. Program accountability

Hal ini dapat dilihat dari penetapan dan pencapaian tujuan yeng telah ditetapkan tersebut.

e. Policy accountability 
Dalam tahap ini dilakukan pemilihan berbagai kebijakan yang akan ditetapkan atau tidak.

\section{Dimensi Akuntabilitas Publik}

Dimensi yang harus dipenuhi dalam pemenuhan akuntabilitas publik menurut Mardiasmo (2009) dibagi menjadi empat. Seperti yang telah dikemukakan oleh Elwood bahwa dimensi akuntabilitas yang harus dipenuhi oleh lembaga publik antara lain:

a. Akuntabilitas kejujuran dan hukum, akuntabilitas kejujuran terkait dengan penghindaran penyalahgunaan jabatan, sedangkan akuntabilitas hukum terkait dengan jaminan adanya kepatuhan terhadap hukum dan peraturan lain yang diisyaratkan dalam penggunaan sumber dana publik.

b. Akuntabilitas proses, akuntabilitas proses terkait dengan apakah prosedur yang digunakan dalam melaksanakan tugas sudah cukup baik dalam hal kecukupan sistem informasi akuntansi, sistem informasi manajemen, dan prosedur administrasi.

c. Akuntabilitas program, akuntabilitas program terkait dengan pertimbangan apakah tujuan yang akan ditetapkan dapat dicapai atau tidak, dan apakah telah mempertimbangkan alternative program yang memberikan hasil optimal dengan biaya minimal.

d. Akuntabilitas kebijakan, akuntabilitas kebijakan terkait dengan pertanggungjawaban pemerintah baik pusat maupun daerah atas kebijakan yang diambil terhadap DPR/DPRD dan masyarakat luas.

\section{Ciri-ciri Pemerintahan Sektor Publik yang Akuntabel}

Pengelolaan keuangan yang baik membuat setiap aktivitas yang dilakukan oleh sektor publik dapat dipertanggungjawabkan secara financial. Oleh karena itu dibutuhkan adanya informasi yang transparan dan akuntabel dalam melaksanakan kinerja dan tindakan seseorang badan hukum atau pimpinan organisasi kepada pihak yang lain yang memiliki hak dan kewenangan untuk meminta pertanggungjawaban (Halim dan Iqbal, 2012). Ciri-ciri pemerintah yang akuntabel yaitu :

a. Mampu menyajikan informasi penyelenggaraan pemerintah secara terbuka, cepat, dan tepat kepada masyarakat.

b. Mampu memberikan pelayanan yang memuaskan bagi masyarakat.

c. Mampu menjelaskan dan mempertanggungjawabkan setiap kebijakan publik secara proporsional.

d. Mampu memberikan ruang bagi masyarakat untuk terlibat dalam proses pembangunan pemerintah.

e. Adanya sarana kepada publik untuk menilai kinerja (performance) pemerintah.

Lembaga sektor publik dapat dikatakan akuntabel apabila dapat menjalankan fungsinya secara maksimal yaitu memberikan pelayanan publik dalam memenuhi kebutuhan dan hak publik serta melengkapi adanya bukti pertanggungjawaban atas kinerja mereka. 
Untuk meningkatkan akuntabilitas publik, pemerintah perlu mengakses laporan keuangan yang dibuatnya agar masyarakat drngan mudah memperoleh laporan keuangan tersebut (Wahyuni, Herawati 2010).

\section{Audit Kinerja}

Mardiasmo (2009) mengatakan bahwa audit kinerja adalah pemeriksaan terkait kinerja/pengelolaan keuangan yang tersaji dalam laporan keuangan yang bertujuan apakah laporan tersebut sudah menggambarkan kejadian aslinya dan apakah pengelolaan itu sudah sesuai dengan ketetapan yang berlaku. Audit yang dilakukan pada sektor pemerintah tidak hanya terbatas pada audit atas laporan keuangan dan audit dengan tujuan tertentu, namun perlu diperluas dengan melakukan audit terhadap kinerja pemerintah tersebut.

Menurut Rai (2008) mengatakan berdasarkan UU No.15 tahun 2004 dan SPKN, audit kinerja adalah audit yang dilakukan secara objektif dan sistematis terhadap berbagai macam bukti untuk menilai kinerja entitas yang diaudit dalam hal ekonomi, efisiensi, dan efektifitas dengan tujuan untuk memperbaiki kinerja dan entitas yang diaudit dan meningkatkan akuntabilitas public.

Audit kinerja memfokuskan pemerikasaan pada tindakan-tindakan dan kejadiankejadian ekonomi yang menggambarkan kinerja entitas atau fungsi yang diaudit. Kinerja suatu organisasi dinilai baik jika organisasi yang bersangkutan mampu melaksanakan tugas-tugas dalam rangka mencapai tujuan yang telah ditetapkan pada standar yang tinggi dengan biaya yang rendah. Secara teknis kinerja yang baik bagi sustu organisasi dicapai ketika administrasi dan penyedia jasa oleh organisasi yang bersangkutan dilakukan pada tingkat yang ekonomis, efesiensi dan efektif.

Konsep ekonomi, efesiensi, efektivitas saling berhubungan satu sama lain dan tidak dapat diartikan/dimaknai secara terpisah atau sendiri-sendiri. Konsep ekonomi memastikan bahwa biaya input yang digunakan dalam operasional organisasi dapat diminimalkan, konsep efesiensi memastikan bahwa output yang maksimal dapat dicapai dengan sumber daya yang tersedia, konsep efektivitas berarti bahwa jasa yang disediakan/dihasilkan oleh organisasi dapat melayani kebutuhan pengguna jasa dengan tepat (Ismet Susila 2008).

Sumaryati dalam Darmawan (2014) menyatakan bahwa strategis audit kinerja sektor publik yaitu : pertama, audit kinerja ditujukan dalam rangka penilaian, perbaikkan dan peningkatan kinerja ekonomi. Kedua, audit kinerja dilakukan dalam rangka peningkatan transparansi dan akuntabilitas publik. Ketiga, audit kinerja dilakukan guna mendorong terciptanya clean government, good government, accountable government baik pada pemerintah pusat maupun pemerintah daerah.

\section{Karakteristik Audit Kinerja}

1. Audit Ekonomi dan Efisiensi (Management audit and Operational audit) Konsep pertama yang ada dalam pengelolaan audit kinerja adalah Ekonomi yang 
berkaitan dengan sejauh mana organisasi dapat meminimalisir input resources yang digunakan, yaitu dengan menghindari pengeluaran yang boros dan tidak produktif.

\section{Konsep yang kedua yaitu Efisiensi}

yang merupakan perbandingan output atau input yang berkaitan dengan standar kinerja atau target yang telah ditetapkan. Dapat disimpulkan bahwa ekonomi mempunyai arti biaya terendah, sedangkan efisiensi lebih mengacu pada perbandingan terbaik antara output dan input yang telah terealisasikan. Audit Ekonomi dan Efisiensi bertujuan untuk menentukan bahwa suatu entitas telah memperoleh, melindungi, menggunakan sumber dayanya ( karyawan, gedung, ruang dan peralatan kantor ) secara ekonomis dan efisien.

\section{Audit Efektivitas}

Efektivitas merupakan tingkat pencapaian hasil program dengan target yang ditetapkan. Audit Efektivitas bertujuan untuk menentukan pencapaian hasil atau manfaat yang diinginkan sesuai tujuan yang telah ditetapkan sebelumnya.

\section{Manfaat Audit Kinerja}

Audit kinerja bermanfaat untuk mengetahui apakah sumber daya organisasi telah diperoleh dan digunakan secara ekonomis, efisien, efektif, dan tidak terjadi pemborosan, kebocoran, salah alokasi, dan salah sasaran dalam mencapai tujuan. Dengan dilakukannya audit kinerja stakeholders sektor publik dapat memperoleh informasi yang objektif dan independen mengenai kinerja manajemen sektor public (Widaryanti et al., 2021). Rahmansyah Ritonga (2013) audit sektor publik tidak hanya memeriksa serta menilai kewajaran laporan keuangan sektor publik, tetapi juga menilai ketaatan aparatur pemerintahan terhadap undang-undang dan peraturan yang berlaku. Disamping itu, auditor sektor publik juga memeriksa dan menilai sifat-sifat hemat (ekonomis), efisien serta keefektifan dari semua pekerjaan, pelayanan atau program yang dilakukan pemerintah. Dengan demikian, bila kualitas audit sektor publik rendah, akan mengakibatkan risiko tuntutan hukum (legitimasi) terhadap pejabat pemerintah dan akan muncul kecurangan, korupsi serta kolusi.

\section{Penyajian Laporan Keuangan}

Bastian (2006) mengatakan bahwa Laporan keuangan sektor publik merupakan representasi terstruktur posisi keuangan akibat transaksi yang dilakukan oleh suatu entitas sektor publik. Secara spesifik laporan dapat menyediakan informasi yang relevan dalam pengambilan keputusan dan menunjukan akuntabilitas entitas atau sumber daya yang dipercayakan.

Pemerintah merupakan hak publik atas informasi keuangan yang bertanggungjawaban untuk memberikan laporan keuangan sebagai bukti pertanggung jawaban dan pengelolaan (accountability and stewardship). Masyarakat sebagai pihak yang memberi kepercayaan kepada pemerintah untuk mengelola keuangan publik berhak untuk mendapatkan informasi keuangan pemerintah. Masyarakat pengguna pelayanan publik membutuhkan informasi atas biaya, harga dan kualitas pelayanan yang diberikan (Mardiasmo, 2009). Oleh 
karena itu, pemerintah berkewajiban untuk memberikan informasi keuangan yang akan digunakan untuk pengambilan keputusan ekonomi, sosial, dan politik oleh pihak-pihak yang berkepentingan. penyajian laporan keuangan sangat penting karena dapat mengukur sejauh mana kinerja yang sudah dilaksanakan dan menjadi alat bukti apakah kinerja sudah sesuai dengan kriteria akuntabel.

\section{Karakteristik kualitatif laporan keuangan}

Bastian (2006) menjelaskan secara rinci mengenai keempat karakteristik kualitatif laporan keuangan sebagai berikut:

a. Relevan yaitu informasi yang termuat dalam laporan keuangan dapat mempengaruhi kebutuhan pengguna dengan membantu mereka mengevaluasi peristiwa masa lalu atau masa kini.

b. Andal yaitu laporan keuangan bebas dari pengertian yang menyesatkan dan kesalahan yang material, menyajikan setiap fakta secara jujur, serta dapat diferivikasi.

c. Dapat dibandingkan yaitu informasi yang termuat dalam laporan keuangan dapat dibandingkan dengan laporan keuangan periode sebelumnya atau entitas pelaporan lain pada umumnya.

d. Dapat dipahami yaitu informasi yang disajikan dalam laporan keuangan dapat dipahami oleh pengguna dan dinyatakan dalam bentuk serta istilah yang disesuaikan dengan batas pemahaman para pengguna untuk mengetahui isi yang dimaksud dalam laporan keuangan.

\section{Tujuan Penyajian Laporan Keuangan}

Nordiawan (2010), tujuan penyajian laporan keuangan adalah :

a. Menyediakan informasi mengenai kecukupan penerimaan periode berjalan untuk membiayai seluruh pengeluaran

b. Menyediakan informasi mengenai kesesuaian cara memperoleh sumber daya ekonomi dan alokasinya dengan anggaran yang ditetapkan

c. Menyediakan informasi mengenai jumlah sumber daya ekonomi yang digunakan

d. Menyediakan informasi mengenai bagaimana entitas pelaporan mendanai seluruh kegiatannya dan mencukupi kebutuhan kasnya

e. Menyediakan informasi pelaporan mengenai posisi keuangan dan kondisi entitas pelaporan berkaitan dengan sumber-sumber penerimaannya

f. Menyediakan informasi mengenai perubahan posisi keuangan entitas pelaporan

Laporan keuangan pada dasarnya adalah hak publik, maka dari itu lembaga sektor publik selaku pihak manajerial harus memberikan ruang yang memadai kepada stakeholder baik dari internal maupun eksternal dalam mengakses laporan keuangan. Pemerintah daerah dituntut untuk dapat menyusun laporan keuangan sesuai standar akuntansi yang diterima umum (Widaryanti, 2007). 


\section{Kerangka Pemikiran}

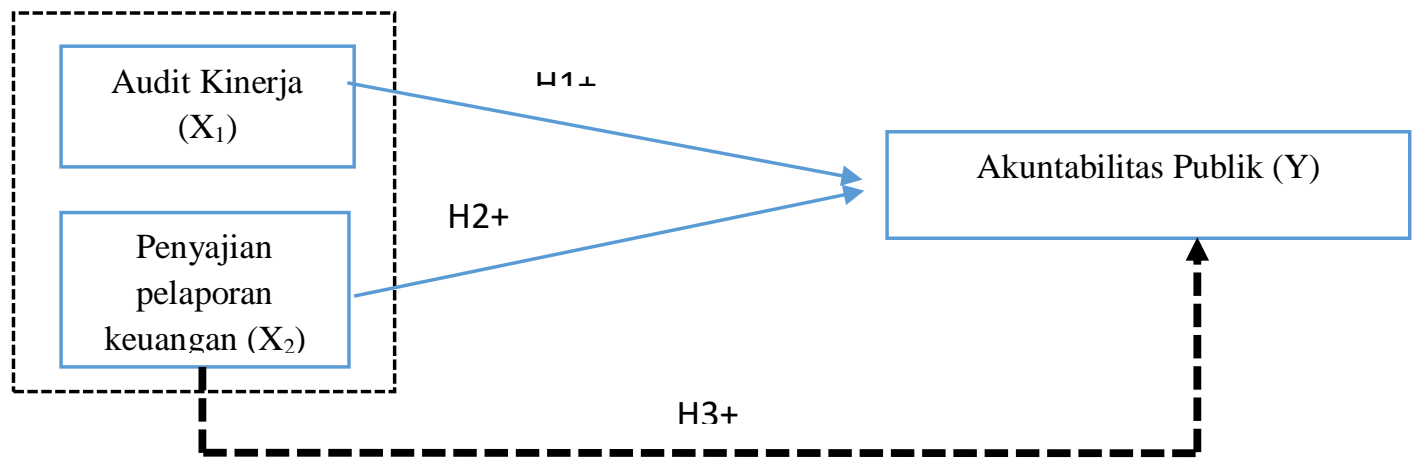

\section{Metode Penelitian}

Data dikumpulkan menggunakan metode angket. Metode angket yaitu menyebarkan daftar pernyataan (kuesioner) yang akan diisi oleh responden. Pengukuran variabelvariabel menggunakan instrumen berbentuk pernyataan tertutup, sehingga responden hanya memilih salah satu jawaban yang telah disediakan.

Jenis data yang digunakan dalam penelitian ini adalah data primer. Data primer dalam penelitian ini diperoleh peneliti secara langsung dengan menyebarkan koesioner kepada responden, yaitu Kepala Bagian dan Staf Subbagian Akuntansi, Kepala urusan bagian Keuangan dan Admnistrasi di masing-masing Dinas yang tergabung dalam Satuan Kerja Perangkat Daerah Kota Semarang.

Populasi merupakan seluruh kumpulan elemen yang menunjukkan ciri-ciri tertentu dan dapat digunakan untuk membuat kesimpulan (Sanusi, 2014).Populasi yang digunakan dalam penelitian ini adalah seluruh badan maupun dinas yang termasuk Satuan Kerja Perangkat Daerah di Kota Semarang, dengan jumlah 21 dinas. Teknik sampling yang digunakan dalam penelitian ini adalah sampel sensus.

\section{Hasil dan Pembahasan}

Berdasarkan hasil kuesioner yang dibagikan kepada Kepala Bagian dan Staf Subbagian Akuntansi, Admnistrasi di masing-masing Dinas yang tergabung dalam Satuan Kerja Perangkat Daerah Kota Semarang, kuesioner yang kembali sebanyak 42 dimana semuanya dapat digunakan sebesar $100 \%$ dihitung dari persentase jumlah kuesioner yang dibagi.

Hasil uji validitas menunjukkan bahwa masing-masing kuesioner memiliki $\mathrm{r}$ hitung dan $r$ tabel ( $r$ hitung > 0,2573) yang berarti masing-masing item dari audit kinerja, penyajian laporan keuangan dan akuntabilitas publik adalah valid.

Berdasarkan uji reliabilitas menunjukkan bahwa audit kinerja, penyajian laporan keuangan, dan akuntabilitas publik dikatakan realibel karena memiliki nilai cronbach alpha lebih tinggi dari 0,7 .

Hasil uji normalitas menunjukkan bahwa model regresi berdistribusi normal karena nilai probabilitas lebih besar dari 0,05, yaitu sebesar 0,093. 
Hasil uji multikolinearitas menunjukkan nilai VIF dari kedua variabel bebas masih lebih kecil dari 10 dan dapat disimpulkan tidak terdapat multikolinearitas diantara kedua variabel.

Tabel 1

Hasil Uji Heteroskedastisitas

\begin{tabular}{|c|c|c|c|c|c|c|}
\hline \multirow{2}{*}{\multicolumn{2}{|c|}{ Model }} & \multicolumn{2}{|c|}{$\begin{array}{c}\text { Untandardized } \\
\text { Coefficients }\end{array}$} & \multirow{2}{*}{$\begin{array}{c}\text { Standardized } \\
\text { Coefficients } \\
\text { Beta }\end{array}$} & \multirow{2}{*}{$\mathrm{t}$} & \multirow[b]{2}{*}{ Sig. } \\
\hline & & B & Std. Error & & & \\
\hline \multirow[t]{6}{*}{1} & (Constant) & $-3,043$ & 1,552 & & $-1,961$ & , 057 \\
\hline & X1_Audit & , 124 & , 150 &, 162 & ,827 & ,413 \\
\hline & Kinerja & & & & & \\
\hline & X2_Penyajian &, 124 &, 104 & ,234 & 1,192 & 240 \\
\hline & Laporan & & & & & \\
\hline & Keuangan & & & & & \\
\hline
\end{tabular}

Hasil uji Glejser pada Tabel 1 di atas menunjukkan bahwa probabilitas untuk semua variabel independen tingkat sig. $\geq 0,05$. Jadi dalam penelitian ini dapat disimpulkan bahwa model regresi tidak mengandung heteroskedastisitas.

\section{Uji Hipotesis}

\section{Uji Regresi Linear Berganda}

Tabel 2

Hasil Regresi Linear Berganda

\begin{tabular}{|c|c|c|c|c|c|c|}
\hline \multirow{2}{*}{\multicolumn{2}{|c|}{ Model }} & \multicolumn{2}{|c|}{$\begin{array}{c}\text { Untandardized } \\
\text { Coefficients }\end{array}$} & \multirow{2}{*}{$\begin{array}{c}\text { Standardized } \\
\text { Coefficients } \\
\text { Beta }\end{array}$} & \multirow{2}{*}{$\mathrm{t}$} & \multirow[b]{2}{*}{ Sig. } \\
\hline & & B & Std. Error & & & \\
\hline \multirow[t]{3}{*}{1} & (Constant) & 3,438 & 2,145 & & 1,602 &, 117 \\
\hline & $\begin{array}{l}\text { X1_Audit } \\
\text { Kinerja }\end{array}$ & ,224 & ,207 & , 185 & 1,080 & ,287 \\
\hline & $\begin{array}{l}\text { X2_Penyajian } \\
\text { Laporan } \\
\text { Keuangan }\end{array}$ & ,369 &, 144 & ,440 & 2,562 & ,014 \\
\hline
\end{tabular}

Berdasarkan tabel 2 maka persamaan regresi pada penelitian ini dapat dijelaskan sebagai berikut:

$Y=3,438+0,224 A K+0,369 P L K+e$ 
Tabel 3

Hasil Uji t

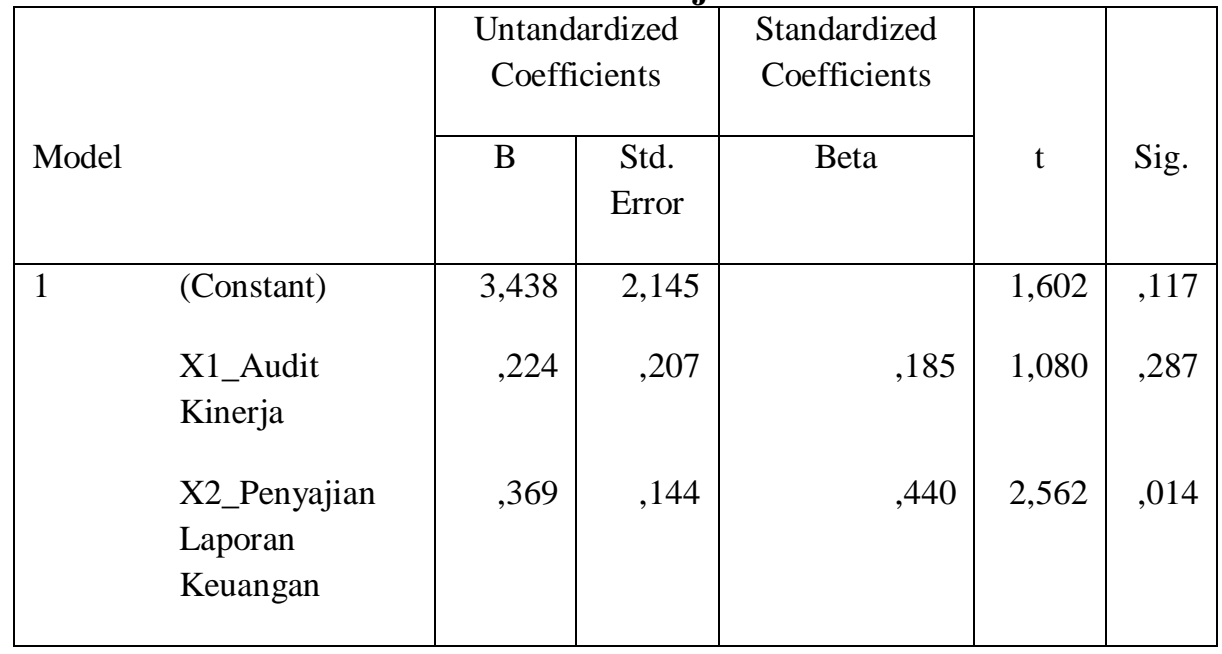

Sumber: Output SPSS 26, 2021

Berdasarkan tabel 3 dapat diketahui hasil uji parsial (uji t) sebagai berikut:

Audit Kinerja tidak berpengaruh terhadap akuntabilitas publik dengan tingkat signifikansi 0,287 > 0,05 sedangkan $t$ hitung 1,080 < 1,683. Maka disimpulkan H1 ditolak yang dapat dikatakan bahwa audit kinerja tidak berpengaruh secara signifikan terhadap akuntabilitas publik.

Penyajian Laporan Keuangan berpengaruh terhadap akuntabilitas publik dengan tingkat signifikasi 0,014 <0,05 sedangkan t hitung 2,562 > t tabel 1,683. Maka disimpulkan H2 diterima maka dapat dikatakan bahwa penyajian laporan keuangan berpengaruh secara signifikan terhadap akuntabilitas publik.

Tabel 4

Hasil Uji Simultan (Uji F)

\begin{tabular}{|cl|l|l|l|l|l|}
\hline & Model & \multicolumn{1}{|c|}{$\begin{array}{c}\text { Sum of } \\
\text { Squares }\end{array}$} & Df & $\begin{array}{c}\text { Mean } \\
\text { Square }\end{array}$ & F & Sig. \\
\hline 1 & Regression & 22,602 & 2 & 11,301 & 9,729 &, $000^{\mathrm{a}}$ \\
& $\begin{array}{l}\text { Residual } \\
\text { Total }\end{array}$ & 45,303 & 39 & 1,162 & & \\
& 67,905 & 41 & & & \\
\hline
\end{tabular}

Sumber: Output SPSS 26, 2021

Diketahui hasil uji statistik F pada Tabel 4 dengan nilai F hitung sebesar 9,729 dengan signifikansi pada tingkat 0,000 . Hal ini dapat dijelaskan dengan tingkat signifikansi 5\% $(\propto=0,05)$ dan $\mathrm{F}$ hitung 9,729 > F tabel 4,084746 dapat diartikan bahwa audit kinerja dan penyajian laporan keuangan dapat diartikan bahwa audit kinerja dan penyajian laporan 
keuangan secara bersama-sama (simultan) berpengaruh positif terhadap akuntabilitas public.

\section{Tabel 5}

Hasil Uji Koefisien Determinasi $\left(\mathbf{R}^{2}\right)$

\begin{tabular}{|l|r|r|r|r|}
\hline Model & \multicolumn{1}{|c|}{$\mathrm{R}$} & R Square & \multicolumn{1}{c|}{$\begin{array}{c}\text { Adjusted } \mathrm{R} \\
\text { Square }\end{array}$} & \multicolumn{1}{c|}{$\begin{array}{c}\text { Std. Error of the } \\
\text { Estimate }\end{array}$} \\
\hline 1 &, $557^{\mathrm{a}}$ &, 333 &, 299 & 1,07778 \\
\hline
\end{tabular}

Sumber: Output SPSS 26, 2021

Hasil analisis regresi dari Tabel 5 dapat diketahui koefisien determinasi Adjusted $R$ Square $\left(\mathrm{R}^{2}\right)$ sebesar 0,299 atau 29,9\% yang berarti audit kinerja dan penyajian laporan keuangan dapat menjelaskan pengaruhnya terhadap akuntabilitas publik sementara sisanya $(100 \%-29,9 \%=70,1 \%)$ dijelaskan oleh variabel lain.

\section{Pembahasan}

\section{Pengaruh Audit Kinerja terhadap Akuntabilitas Publik}

Berdasarkan hasil perhitungan dengan uji parsial (uji t) menunjukkan bahwa audit kinerja tidak berpengaruh terhadap akuntabilitas publik ini menunjukkan udit kinerja pada SKPD Kota Semarang berdasarkan hasil tanggapan responden secara keseluruhan dinyatakan baik, akan tetapi masih ada indikator yang berkreteria cukup yaitu : efisien dan efektifitas, sehingga belum memenuhi ketentuan yang berlaku. Audit ekonomi dan efisiensi bertujuan untuk menentukan bahwa suatu entitas telah memperoleh, melindungi, menggunakan sumber dayanya. Kinerja suatu organisasi dinilai baik jika organisasi yang bersangkutan mampu melaksanakan tugas-tugas dalam rangka mencapai tujuan yang telah ditetapkan pada standar yang tinggi dengan biaya yang rendah. Kinerja yang baik bagi suatu organisasi dicapai ketika administrasi dan penyediaan jasa oleh organisasi yang bersangkutan dilakukan pada tingkat yang ekonomis, efisien dan efektif. Konsep ekonomi, efisiensi dan efektivitas saling berhubungan. Dari konsep tersebut dimaksudkan untuk mengidentifikasi penyebab terjadinya praktik-praktik adanya penyimpangan yang berhubungan dengan akuntabilitas publik, sehingga auditkinerja SKPD Kota Semarang dalam melakukan pemeriksaan kinerja harus menekankan kegiatan yang dibiayai dengan keuangan negara secara ekonomis, efisien, serta memenuhi sasaran yang efektif.

\section{Pengaruh Penyajian Laporan Keuangan Terhadap Akuntabilitas Publik}

Berdasarkan hasil perhitungan dengan uji parsial (uji t) menunjukkan bahwa penyajian laporan keuangan berpengaruh positif dan signifikan. Bahwa akuntabilitas publik merupakan pertanggungjawaban yang dilakukan pemerintah atas aktivitasaktivitas dan kinerjanya yang dilakukan oleh pihak-pihak yang berkepentingan. Dengan demikian, melalui penyajian laporan keuangan yang baik, maka kualitas penyajian laporan keuangan yang terlaksana secara optimal akan memberikan pengaruh positif 
terhadap akuntabilitas publik pada SKPD Kota Semarang, sehingga dapat dipertanggungjawabkan kebenarannya dalam menyampaikan laporan keuangan.

\section{Simpulan}

Berdasarkan hasil penelitian maka dapat disimpulkan sebagai berikut :

Audit kinerja tidak berpengaruh terhadap akuntabilitas publik.

Penyajian laporan keuangan berpengaruh positif dan signifikansi terhadap akuntabilitas publik.

Audit kinerja dan penyajian laporan keuangan secara bersama-sama atau simultan berpengaruh terhadap akuntabilitas publik.

\section{Saran}

Penelitian ini hanya menggunakan beberapa sampel yang ada di SKPD Kota Semarang. Untuk penelitian selanjutnya sebaiknya memperluas wilayah sampel, tidak hanya beberapa SKPD diKota Semarang. Hal tersebut bertujuan agar responden penelitian banyak dan mendapatkan hasil yang maksimal. Penelitian selanjutnya sebaiknya menambah variabel-variabel lain yang mempengaruhi akuntabilitas publik. Hal tersebut dikarenakan besarnya adjusted $\mathrm{R}^{2} 0,299$ atau $29,9 \%$, dan sisanya $(100 \%-29,9 \%=$ $70,1 \%$ ) dijelaskan oleh variabel lain.

\section{Daftar Pustaka}

Abdul Halim. 2007. Akuntansi Sektor Publik : Akuntansi Keuangan Daerah: Salemba Empat. Jakarta.

Aliyah, Siti dan Aida Nahar. 2012. Pengaruh Penyajian Laporan Keuangan Daerah dan Alsesibilitas Laporan Keuangan Daerah terhadap Transpransi dan Akuntabilitas Pengelolaan Keuangan Daerah Kabupaten Jepara. Jurnal Akuntansi \& Auditing, Volume 8, Nomor 2 (hlm.137-150).

Ankarat. 2012. "Penyajian Laporan Keuangan". Artikel on-line. Melalui <http:// yulimel-s. blogspot.com /2013/09/ teori-akuntansi-penyajian-laporan.html $[12 / 03 / 14]>$

Bastin, Indr. 2006. Akuntansi Sektor Publik: Suatu Pengantar. Jakarta : Erlangga.

Hudana, Revy Septhian. 2011. Pengaruh Audit Kinerja Sektor Publik dan Indepedensi Auditor terhadap Akuntabilitas Publik. Skripsi. UNIKOM. Bandung

https://amp.suara.com/yoursay/2020/06/24/144004/dampak-work-from-home

https://bkd.jabarprov.go.id/artikel/202-dampak-sosial-pandemi-covid-19

https://fajar.co.id/2018/09/13/kepala-bpkad-makasar-terjerat-dugaan-korupsi.1

Indra Bastian. 2007. Audit Sektor Publik. Ed. 2. Salemba Empat: Jakarta 
I Gusti Agung Rai. 2008. Audit Kinerja Pada Sektor Publik. Jakarta: Salemba Empat.

Ismet Susila. 2008. Audit Kinerja Sektor Publik. Inovasi, Volume 5, Nomor 2, (1-23)

Kristianto, Yudi. 2011. Pengaruh Aksesibilitas Laporan Keuangan dan Audit Kinerja terhadap Akuntabilitas Publik (Studi pada Pemerintah Kota Bandung). Skripsi. Universitas Komputer Indonesia, Bandung.

Lintje Kalangi. 2012. Peranan Auditing Sektor Publik Terhadap Akuntabilitas Publik Pemerintah Daerah. Jurnal Riset Akuntansi dan Auditing. Volume 3-Nomor 2 $(1-8)$

Nurhayani, H. (2013). Pengaruh penyajian dan aksesibilitas laporan keuangan terhadap akuntabilitas pengelolaan keuangan daerah (survey pada seluruh dinas pemerintahan kota bandung). Universitas Komputer Indonesia.

Mardiasmo. 2002. Akuntansi Sektor Publik. Yogyakarta: ANDI Yogyakarta.

Mulyana, Budi. 2006. Pengaruh Penyajian Neraca Daerah dan Aksesibilitas Laporan Keuangan Terhadap Transparansi dan Akuntabilitas Pengelolaan Keuangan daerah,. Jurnal Akuntansi pemerintah Vol 2, No.1. Jakarta.

Mustofa. 2012. Pengaruh Penyajian dan Aksebilitas Laporan Keuangan Kabupaten Pemalang. Accounting Analysis Journal, Volume 1, Nomor 1, (hlm. 1-6)

Nasution, Saufi Iqbal, 2009. Pengaruh Penyajian Neraca SKPD dan Aksesibilitas Laporan Keuangan SKPD Terhadap Transparansi dan Akntabilitas Pengelolaan Keuangan SKPD, Skripsi, Jurusan Akuntansi, FakultasEkonomi, Universitas Sumatera Utara, Medan.

Primayani, P.R,. Herawaty, N.T., dan Darmawan, N.A.S. (2014). Pengaruh Penyajian dan Aksebilitas Laporan Keuangan terhadap Akuntabilitas Pengelolaan Keuangan Daerah (Studi Empiris pada Pemerintah Kabupaten Bandung). EJournal S1 Ak Universitas Pendidikan Ganesha Jurusan Akuntansi Program S1 (Volume 2 No. 1 Tahun 2014).

Putu Sri Wahyuni, dkk. 2014. Pengaruh Penyajian Laporan keuangan Daerah dan Aksebilitas Laporan Keuangan Daerah terhadap Akuntabilitas Pengelolaan Keuangan Daerah. Volume 2 No.1 Tahun 2014)

Rahayu, Cici. 2011. Pengaruh Audit Kinerja Sektor Publik dan Pengawasan Fungsional terhadap Akuntabilitas Publik pada Satuan Kerja Perangkat Daerah 
(SKPD) di pemerintah Kota Cimahi. Skripsi. Universitas Komputer Indonesia, Bandung.

Rahmansyah Ritonga. 2013. Optimalisasi Audit Kinerja Instansi Pemerintah.

Rai, I Gusti Agung. 2008. Audit Kinerja Sektor Publik. Jakarta : Salemba Empat.

Sagala, Marjuki, 2011, Pengaruh Penyajian Laporan Keuangan Daerah dan Aksesibilitas Laporan Keuangan terhadap Transparansi dan Akuntabilitas Pengelolaan Laporan Keuangan. Skripsi, Fakultas Ekonomi, Universitas Sumatera Utara. Medan.

Sande. Peggy. 2013. Pengaruh Penyajian Laporan Keuangan dan Aksesibilitas Laporan Keuangan terhadap Akuntabilitas Pengelolaan Keuangan Daerah (Studi Empiris pada Pemerintah Provinsi Sumatera Barat). Artikel Skripsi. Universitas Negeri Padang.

Sardjiarto, A. (2000). Akuntabilitas dan pengukuran kinerja pemerintah. Jurnal Akuntansi dan Keuangan Vol. 2, No. 2, November 2000: 138 - 150.

Sukhemi, 2010. Pengaruh Penyajian Neraca Daerah Terhadap Akuntabilitas Keuangan Daerah. Universitas PGRI Yogyakarta.

Supardi, Deddy. Wiarty, Sheirly. 2009. Peranan Audit Kinerja dalam Akuntabilitas. UNIKOM. Vol. I, No. 2. April. Hlm. 77-94.

Ulum, Ihyaul. 2009. Audit Sektor Publik Suatu Pengantar. Jakarta : Bumi Aksara.

Wiarty. 2009. Peranan Audit Kinerja dalam Menunjang Akuntabilitas Publik Pemerintah Kota Bandung (Studi Penelitian pada Dinas Pendapatan). Skripsi. Universitas Komputer Indonesia, Bandung.

Widaryanti. (2007). Etika Bisnis dan Etika Profesi Akuntan. Fokus Ekonomi, 2(1), 110.

Widaryanti, W., Putra, A., \& Timotius, E. (2021). The Implications of Digital Transformation on Developing Human Resources in Business Practice in Indonesian: Analysis of the. International Journal of Business, Economics \& Management, 4(1), 157-164.

https://doi.org/https://doi.org/10.31295/ijbem.v4n1.1425

Widilestariningtyas, O., dan Wildani, O. (2014). Pengaruh audit kinerja dan aksesibilitas laporan keuangan. Universitas Komputer Indonesia.

Wulandari, I. (2013). Pengaruh pengawasan fungsional dalam menunjang akuntabilitas publik pada pemerintah kota padang. Artikel. Padang: Fakultas Ekonomi Universitas Negeri Padang. 